\title{
UPAYA MENUMBUHKAN KARAKTER IPA \\ MELALUI REFLEKSI PENILAIAN DIRI PESERTA DIDIK PADA SISWA \\ KELAS VIII D SMP NEGERI 1 BANDUNGAN \\ TAHUN PELAJARAN 2014/ 2015
}

Eni Riptyawati

SMP Negeri 1 Bandungan

eni.riptya@gmail.com

\begin{abstract}
ABSTRAK
Pendidikan karakter pada mata pelajaran IPA merupakan cara yang tepat untuk membentuk pribadi peserta didik yang berakhlak mulia. IPA merupakan salah satu pelajaran yang sudah menerapkan pendidikan karakter dalam proses pembelajarannya. Refleksi penilaian diri peserta didik merupakan salah satu cara untuk menumbuhkan karakter tersebut. Tujuan penelitian ini adalah untuk menumbuhkan karakter jujur dan peduli pada lingkungan. Penelitian ini terdiri dari dua siklus yang masing-masing siklus terdiri dari perencanaan, pelaksanaan tindakan, observasi dan refleksi. Hasil penelitian menunjukkan adanya peningkatan karakter jujur dan peduli pada lingkungan Hal ini dapat diketahui dari hasil observasi penilaian diri peserta didik. Dengan demikian dapat disimpulkan bahwa refleksi penilaian diri peserta didik dapat digunakan untuk menumbuhkan karakter IPA (jujur dan peduli pada lingkungan).
\end{abstract}

Kata kunci: pendidikan karakter, refleksi, penilaian diri, jujur, dan peduli lingkungan 


\section{PENDAHULUAN}

Pendidikan Nasional secara umum bertujuan untuk mengembangkan potensi peserta didik agar menjadi manusia yang beriman dan bertaqwa kepada Tuhan yang Maha Esa, berakhlak mulia, sehat, berilmu, cakap, kreatif, mandiri dan menjadi warga negara yang demokratis serta bertanggung jawab (Sisdiknas, 2003). Dalam upaya mendukung tujuan tersebut, perlu ditanamkan pendidikan karakter dalam setiap proses pembelajaran. Hal ini sangat beralasan karena pendidikan karakter merupakan pondasi utama bagi pembentukan akhlak dan kepribadian peserta didik. Pemerintah menganjurkan agar sekolah-sekolah menggunakan pendidikan karakter, model pendidikan konvensional dipandang sudah tidak mampu untuk menghalau arus deras dampak globalisasi (Oci, 2012).

Seyogyanya prestasi kognitif diimbangi pula dengan sikap yang baik pada diri peserta didik. Suasana kelas akan kondusif jika karakter yang diharapkan pada diri masing-masing peserta didik sudah terbentuk. Guru sudah tidak lagi menyuruh peserta didik untuk membersihkan kelas setiap hari, membuang sampah di tempatnya, mengerjakan PR atau tugas di rumah, tidak menyontek saat ulangan, melaksanakan tugas piket kebersihan kelas dan selalu patuh pada tata tertib. Apabila sikap tersebut sudah tertanam pada diri peserta didik, maka diharapkan pembelajaran di kelas dapat berjalan dengan baik dan pada akhirnya dapat terbentuk generasi muda yang cerdas, jujur, peduli lingkungan, berwatak dan kompetitif.

Namun demikian yang terjadi justru sebaliknya, akhir-akhir ini banyak dijumpai semakin merosotnya moral generasi muda kita, kurangnya sikap menghargai terhadap lingkungan serta perkelahian antar pelajar yang semakin marak terjadi di berbagai daerah. Keadaan seperti ini sering peneliti lihat pada diri siswa kelas VIII D SMP Negeri 1 Bandungan yang merupakan kumpulan peserta didik yang memerlukan penanganan secara khusus dalam pembelajaran dibandingkan dengan kelas yang lainnya. Kondisi kelas yang selalu kotor karena peserta didik belum melaksanakan piket kebersihan kelas walaupun telah dibagikan jadwal piket kebersihan, membuang sampah sembarangan, menggunakan atribut seragam yang tidak lengkap, sering mencontek saat ulangan, mengerjakan PR atau tugas rumah di sekolah, dan pelanggaran lain yang sering dilakukan oleh siswa kelas tersebut. Akibatnya setiap pelajaran IPA akan dimulai, guru harus menggunakan 5 sampai 10 menit terlebih dahulu hanya untuk menyuruh siswa membersihkan kelas yang kotor atau menunda waktu pembelajaran beberapa menit karena hampir $40 \%$ siswa belum mengerjakan tugas atau PR. Ketika diadakan ulangan harian pun hampir $60 \%$ siswa gelisah karena ingin membuka contekan ataupun melirik teman di sebelahnya, sehingga menyebabkan kelas menjadi tidak kondusif.

Hal yang sama juga terlihat ketika siswa kelas VIII D diajak praktikum di laboratorium, setelah selesai praktikum mereka belum mempunyai kesadaran sendiri untuk membersihkan tempat praktikumnya, sampah hasil praktikun masih dibiarkan berantakan di meja, sehingga guru harus memerintahkan setiap kelompok untuk membersihkan tempat praktikumnya masing-masing.

Pendidikan di sekolah masih dianggap merupakan tempat yang sangat penting untuk mengubah karakter peserta didik. Tugas guru tidak hanya menyampaikan materi pelajaran kognitif saja, tetapi sekarang guru juga dituntut untuk dapat menumbuhkan karakter peserta didik. Peserta didik tidak cukup diberi bekal pembelajaran intelektual saja, tetapi harus diberi pembelajaran moral dan spiritual. 
Ilmu pengetahuan Alam (IPA) merupakan salah satu mata pelajaran yang sudah menerapkan pendidikan berkarakter dalam proses pembelajarannya. Pendidikan karakter dapat menjadi penyeimbang kecakapan kognitif. Karakter yang dimiliki mata pelajaran IPA antara lain berpikir logis, kritis, kreatif dan inovatif, jujur, bergaya hidup sehat, percaya diri, menghargai keberagaman, disiplin, mandiri, bertanggung jawab, peduli lingkungan dan cinta ilmu. Pembelajaran dan penilaian mata peajaran IPA meliputi aspek pengetahuan, keterampilan dan sikap.

Penilaian sikap dengan melalui penilaian diri peserta didik dapat dijadikan pemecahan masalah di atas. Penilaian diri merupakan teknik penilaian dengan cara meminta peserta didik untuk mengemukakan kelebihan dan kekurangan dirinya dalam konteks pencapaian kompetensi. Teknik penilaian diri dapat digunakan untuk menilai aspek sikap peserta didik. Penggunaan teknik ini dapat memberikan dampak positif terhadap perkembangan kepribadian seseorang. Hasil dari penilaian diri tersebut kemudian direfleksikan kembali, sehingga siswa akan tahu kelebihan dan kekurangan dirinya serta dapat memperbaiki diri pada pertemuan berikutnya.

Pendapat serupa juga diungkapkan oleh Abdul Rohman (2011), bahwa penilaian diri sebagai teknik penilaian akan sangat efektif untuk menggali nilai-nilai spiritual, moral, motif, sikap, bahkan aspek motorik dan kognitif siswa. Dengan teknik ini peserta didik diajak secara objektif untuk melihat ke dalam dan keadaan dirinya sendiri, sekali lagi dengan jujur dan jernih. Dampak positif lain dari efektivitas teknik penilaian diri adalah peserta didik akan dikondisikan dan dibiasakan untuk selalu jujur. Dan jika anak selalu menjaga kondisi sikap dirinya, ini sangat positif bagi upaya pembangunan karakter anak.

Williams \& Schnaps (1999) (dalam Haryanto: 2012) mendefinisikan pendidikan karakter sebagai "any deliberate approach by which school personnel, often in conjunction with parents and community members, help children and youth become caring, principled and responsible". Makna dari pendidikan karakter yaitu merupakan berbagai usaha yang dilakukan oleh para personil sekolah, bahkan dilakukan bersama-sama dengan orang tua dan anggota masyarakat, untuk membantu anak-anak dan remaja agar menjadi atau memiliki sifat peduli, berpendirian, dan bertanggung jawab. Pendidikan karakter merupakan usaha yang disengaja untuk mengembangkan karakter yang baik berdasarkan nilai-nilai inti yang baik untuk individu dan masyarakat (Reni, 2013).

Sedikitnya ada empat alasan mendasar mengapa sekolah pada masa sekarang perlu bersungguhsungguh menjadikan dirinya tempat tebaik bagi pendidikan karakter yaitu (1) karena banyak keluarga (tradisional maupun non tradisional) yang tidak melaksanakan pendidikan karakter; (2) sekolah tidak hanya bertujuan membentuk anak yang cerdas, tetapi juga anak yang baik; (3) kecerdasan seorang anak hanya bermakna manakala dilandasi dengan kebaikan; dan (4) karena membentuk anak didik agar berkarakter tangguh bukan sekedar tugas tambahan guru, melainkan tanggung jawab yang melekat pada perannya sebagai seorang guru. (Saptono, 2011:25)

Menurut BPPPN Pusat Kurikulum, nilai-nilai karakter perlu dijabarkan sehingga diperoleh deskripsi yang berguna sebagai batasan atau tolak ukur ketercapaian pelaksanaan nilai-nilai pendidikan karakter di sekolah antara lain sebagai berikut: 


\begin{tabular}{lllll}
\hline \multicolumn{1}{c}{ Nilai } & \multicolumn{2}{c}{ Deskripsi } & \multicolumn{2}{c}{ lindikator } \\
\hline Jujur & $\begin{array}{l}\text { Perilaku yang didasarkan pada upaya } \\
\text { menjadikan dirinya sebagai orang yang }\end{array}$ & $\begin{array}{l}\text { - Tidak mencontek ataupun plagiat dalam } \\
\text { mengerjakan setiap tugas }\end{array}$ \\
& $\begin{array}{l}\text { selalu dapat dipercaya dalam } \\
\text { perkataan, tindakan dan pekerjaan }\end{array}$ & $\begin{array}{l}\text { Mengembalikan barang yang dipinjam } \\
\text { atau ditemukan di tempat umum }\end{array}$ \\
\hline Peduli & Sikap dan tindakan yang selalu & - Mengikuti berbagai kegiatan berkenaan \\
lingkung & berupaya mencegah kerusakan pada & dengan kebersihan,keindahan dan \\
an & lingkungan alam sekitarnya dan & pemeliharaan lingkungan. & \\
& mengembangkan upaya-upaya untuk & - Membuang sampah di tempat sampah \\
& memperbaiki kerusakan alam yang & & \\
& sudah terjadi.
\end{tabular}

Menurut petunjuk teknis pengelolaan penilaian pada kurikulum 2013, penilaian diri merupakan teknik penilaian dengan cara meminta peserta didik untuk mengemukakan kelebihan dan kekurangan dirinya dalam konteks pencapaian kompetensi. Instrumen yang digunakan berupa lembar penilaian diri degan menggunakan daftar cek atau skala penilaian yang disertai rubrik.

Penilaian diri (self-assessment) merupakan bentuk penilaian otentik yang penting untuk dilakukan di kelas, siswa merupakan penilai yang baik (the best assessor) terhadap perasaan dan pekerjaan mereka sendiri. Ketika siswa menilai pekerjaan mereka sendiri, maka tanggung jawab untuk belajar adalah mereka sendiri. Oleh karena itu, guru dapat memulai proses penilaian diri dengan memberi kesempatan siswa untuk melakukan validasi pemikiran mereka sendiri atau jawaban-jawaban hasil pekerjaan mereka (Fatimah, 2011). Penilaian diri adalah pembelajaran yang berorientasi berdasarkan instrumen yang dapat menilai kompetensi pendidikan. Penilaian diri dapat menciptakan pembelajaran sepanjang hayat (Basuni, 2009).

Refleksi dilakukan agar siswa memikirkan kembali apa yang telah mereka pelajari dan lakukan selama proses pembelajaran untuk membantu mereka menemukan makna personal masing-masing. Refleksi biasanya dilakukan pada akhir pembelajaran antara lain melalui diskusi, tanyajawab, penyampaian kesan dan pesan, menulis jurnal, saling memberi komentar karya, dan catatan pada buku harian. Refleksi dalam pembelajaran antara lain dapat menumbuhkan kemampuan berfikir logis dan kritis, mengetahui kelebihan dan kekurangan diri sendiri, dan menghargai pendapat orang lain (M.Khusniati, 2012).

Refleksi merupakan proses untuk melihat diri sendiri yang dapat digunakan untuk perbaikan sikap selanjutnya. Kecerdasan anak tidak hanya diukur dari segi inteltualnya saja, tetapi dapat dilihat dari potensi yang lainnya, salah satunya kecerdasan diri (intrapersonal).

Refleksi penilaian diri peserta didik merupakan usaha yang dilakukan untuk dapat mengubah sikap yang tidak baik menjadi sikap yang baik. Melalui refleksi penilaian diri, peserta didik diharapkan dapat melihat sikap dirinya yang kurang baik misalnya selalu membuang sampah sembarangan, menyontek saat ulangan ataupun tidak patuh pada tata tertib sekolah, selanjutnya dapat menjadi renungan bagi dirinya untuk mengubah sikap tersebut. Dalam hal ini guru selalu menayangkan hasil penilaian diri peserta didik, kemudian peserta didik diajak untuk instropeksi diri terhadap hasil 
penilaian terhadap dirinya sendiri. Melalui refleksi penilaian diri, peserta didik dapat mengubah sikap yang tidak baik menjadi sikap yang baik, sehingga pembentukan karakter peserta didik dapat terwujud dengan baik.

Tujuan penelitian ini adalah menumbuhkan karakter IPA (jujur dan peduli pada lingkungan) melalui refleksi penilaian diri peserta didik pada siswa kelas VIII D SMP Negeri 1 Bandungan Tahun Pelajaran 2014/ 2015.

\section{METODE PENELITIAN}

Penelitian ini mengambil subyek siswa kelas VIII D SMP Negeri 1 Bandungan. Teknik pengumpulan data diperoleh melalui lembar observasi penilaian diri peserta didik yang diperoleh setiap pertemuan pada siklus 1 dan siklus 2. Alat pengumpul data berupa hasil rekapitulasi penilaian diri peserta didik. Data yang diperoleh dianalisis secara kualitatif dengan teknik deskripsi kualitatif.

Penelitian ini menggunakan 2 siklus, setiap siklus terdiri dari 4 tahap yaitu: perencanaan, pelaksanaan tindakan, observasi dan refleksi. Pada tahap perencanaan, yang dilaksanakan adalah: (1) guru menyusun RPP yang berkarakter bersama observer; (2) Guru menetapkan karakter IPA yang akan dicapai; (3) Menyusun pertanyaan yang sesuai untuk menumbuhkan karakter IPA yang akan dicapai. Karakter yang akan dicapai pada penelitian ini adalah jujur dan peduli pada lingkungan; (4) Menyusun lembar penilaian peserta didik dan lembar penilaian sikap; (5) Menyusun rubrik penilaian.

Tahap pelaksanaan, peneliti melaksanakan pembelajaran yaitu: (1) Sebelum pelajaran dimulai, guru melakukan pengecekan terhadap kebersihan kelas; (2) Guru mengecek tugas rumah yang telah diberikan pada peserta didik; (3) Guru melakukan pengamatan dan penilaian sikap setiap peserta didik selama mengikuti pelajaran, praktikum dan saat ulangan; (4) Setelah selesai pembelajaran, guru membagikan lembar penilaian diri untuk diisi peserta didik; (5) Guru memberikan informasi tentang kriteria penilaian untuk setiap sikap yang akan dinilai; (6) Guru memberikan motivasi agar peserta didik berlaku jujur saat mengisi lembar penilaian diri; (7) Guru merekap hasil penilaian diri peserta didik; (8) Guru menayangkan nilai hasil penilaian diri peserta didik, kemudian guru meminta peserta didik untuk merefleksikan hasil penilaian diri yang telah diisi peserta didik; (9) Guru memberikan motivasi kepada peserta didik yang belum menunjukkan sikap kurang baik untuk memperbaiki pada pertemuan selanjutnya serta memberikan reward pada peserta didik yang sudah menunjukkan sikap baik; (10) Tindak lanjut hasil penilaian sikap setiap pertemuan dijadikan dasar untuk melakukan proses pembinaan dan pengembangan sikap peserta didik dalam upaya menumbuhkan karakter jujur dan peduli pada lingkungan.

Tahap observasi merupakan pengumpulan data yang bersifat trianggulasi yaitu data berasal dari siswa, guru dan kolaborator. Jenis data terdiri dari data kualitatif. Alat pengumpul data berupa hasil rekapitulasi penilaian diri peserta didik. Pada tahap ini observer memberikan masukan data berupa penilaian perkembangan sikap peserta didik.

Tahap terakhir adalah refleksi, data yang diperoleh dari hasil observasi selama proses pembelajaran dilakukan analisa dan dilakukan refleksi sebagai bahan penyusun rencana tindakan pada siklus berikutnya. Refleksi dilakukan pada sikap peserta didik ketika megikuti ulangan harian, mengerjakan PR, melaksanaka piket kelas, membuang sampah di tempatnya dan membersihkan tempat 
praktikum setelah selesai kegiatan praktikum. Guru membantu peserta didik untuk merefleksikan sikapnya melalui penilaian diri serta memberikan penguatan pada peserta didik yang masih memberikan nilai 1 pada pernyataan yang dijawabnya.

Penumbuhan karakter IPA pada siswa kelas VIII D SMP Negeri 1 Bandungan dikatakan berhasil apabila standar kompetensi yang diharapkan tercapai. Indikatornya adalah apabila $75 \%$ siswa sudah menunjukkan perubahan karakter melalui lembar penilaian diri.

\section{HASIL PENELITIAN DAN PEMBAHASAN}

Hasil penelitian tindakan kelas menumbuhkan karakter pada mata pelajaran IPA khususnya jujur dan peduli lingkungan melalui refleksi penilaian diri dari siklus satu dan siklus dua dapat dilihat pada Tabel. 1.1 dan Tabel 1.2 berikut ini:

Tabel 1.1 Rekapitulasi Hasil Penelitian

\begin{tabular}{|c|c|c|c|c|c|c|c|}
\hline \multirow{3}{*}{ No } & \multirow{3}{*}{ Pernyataan } & \multicolumn{6}{|c|}{$\%$ pencapaian } \\
\hline & & \multicolumn{2}{|c|}{ Kondisi awal } & \multicolumn{2}{|c|}{ Siklus 1} & \multicolumn{2}{|c|}{ Siklus 2} \\
\hline & & $\mathbf{Y a}$ & Tidak & Ya & Tidak & $\mathbf{Y a}$ & Tidak \\
\hline A & Karakter Jujur & & & & & & \\
\hline 1. & Saya menyontek saat ulangan & 53.3 & 46.7 & 43.3 & 56.7 & 26.7 & 73.3 \\
\hline 2. & Saya mengerjakan PR di Sekolah & 46.7 & 53.3 & 36.7 & 63.3 & 23.3 & 76.7 \\
\hline B & Karakter Peduli Pada Lingkungan & & & & & & \\
\hline 3. & $\begin{array}{l}\text { Saya membuang sampah di tempat } \\
\text { sampah }\end{array}$ & 60.0 & 40.0 & 66.7 & 33.3 & 76.7 & 23.3 \\
\hline 4. & $\begin{array}{l}\text { Saya melaksanakan piket kelas } \\
\text { (menyapu kelas) }\end{array}$ & 56.7 & 43.3 & 66.7 & 33.3 & 80.0 & 20.0 \\
\hline 5. & $\begin{array}{l}\text { Saya membersihkan meja praktikum } \\
\text { setelah selesai praktikum }\end{array}$ & 46.7 & 53.5 & 60.0 & 40.0 & 73.3 & 26.7 \\
\hline
\end{tabular}

Rerata Kenaikan Karakter Setiap Siklus

Tabel 1.2 Kenaikan Karakter

\begin{tabular}{llcc}
\hline \multirow{2}{*}{ No } & \multirow{2}{*}{ Karakter } & \multicolumn{2}{c}{ \% Kenaikan } \\
\cline { 3 - 4 } & & Awal ke siklus 1 & Siklus 1 ke siklus 2 \\
\hline 1 & Jujur & 10 & 15 \\
\hline 2 & Peduli Pada Lingkungan & 10 & 12.2 \\
\hline
\end{tabular}

Berdasarkan dari penilaian terhadap refleksi penilaian diri peserta didik pada siklus 1 , sudah tampak perubahan karakter IPA tetapi belum sesuai yang diharapkan yaitu sikap jujur dan peduli lingkungan. Kelas tampak kotor karena regu piket kelas belum melaksanakan tugasnya dan peserta 
didik belum mempunyai kesadaran untuk menjaga kebersihan kelasnya. Pada saat ulangan harianpun lebih dari $40 \%$ peserta didik gelisah.

Pada awal siklus 1, guru memberitahukan tentang karakter IPA yang harus dimiliki oleh peserta didik yaitu jujur dan peduli pada lingkungan. Pada saat melakukan kegiatan pembelajaran/ praktikum, guru selalu menanamkan karakter peduli lingkungan pada peserta didik, misalnya untuk membersihkan tempat praktikum, dan karakter jujur pada saat ulangan, yaitu untuk tidak menyontek. Setelah kegiatan pembelajaran berakhir, guru memberikan lembar penilaian diri serta menayangkan hasil rekapitulassi penilaian diri pertemuan sebelumnya untuk dilakukan refleksi. Refleksi yang dilakukan meliputi nilai-nilai karakter jujur dan peduli lingkungan yang telah dijawab peserta didik. Guru bertanya kepada peserta didik yang masih menuliskan angka 1 pada lembar penilaiannya.

Setelah dilakukan refleksi melalui penayangan hasil rekapitulasi penilaian diri, ternyata terdapat perubahan pada siklus 1, walaupun belum menunjukkan perubahan sikap yang signifikan. Pada kondisi awal rerata prosentase karakter jujur 50\% sedangkan rerata karakter peduli pada lingkungan sebesar $54,5 \%$. Setelah dilakukan tindakan pada siklus 1 yaitu refleksi melalui penayangan rekapitulasi penilaian diri peserta didik, terjadi kenaikan rerata prosentase karakter jujur sebesar $10 \%$ dan karakter peduli pada lingkungan naik 10\% dari kondisi awal.

Karakter jujur masih jauh dari harapan, karena masih ada $40 \%$ peserta didik masih menyontek saat ulangan dan mengerjakan PR di sekolah dan hampir 35,5\% peserta didik belum peduli pada lingkungan. Hasil yang kurang sesuai harapan ini diakibatkan guru kurang memotivasi siswa untuk selalu bersikap baik terutama jujur dan peduli pada lingkungan. Guru hanya sekedar membagikan lembar penilaian diri peserta didik tanpa memberikan penguatan pada mereka tentang pentingnya menumbuhkan karakter IPA dalam diri peserta didik. Akibatnya banyak peserta didik yang beranggapan bahwa lembar penilaian diri hanyalah sekedar tugas menjawab pernyataan-pernyataan yang ada di lembar penilaian diri saja tanpa mengetahui manfaat bagi diri dan lingkungannya.

Pada siklus 1 ini dilakukan dua kali pertemuan, perubahan sikap peserta didik pada pertemuan pertama dan kedua belum menunjukkan kenaikan yang berarti. Keadaannya masih seperti kondisi awal walaupun tidak separah kondisi awal. Kelas terkadang masih sering kotor, masih banyak yang belum mengerjakan PR, gelisah saat ulangan dan ketika diajak praktikum pun masih ada beberapa peserta didik yang belum mempunyai kesadaran sendiri untuk membersihkan tempat praktikumnya setelah selesai kegiatan. Pada awal pembelajaran guru masih harus menggunakan waktu beberapa saat untuk menyuruh regu piket menyapu kelas karena ada beberapa anggota regu piket yang tidak mau melaksanakan tugasnya. Sampah masih ada yang tercecer di bawah meja karena beberapa peserta didik belum mempunyai kesadaran membuangnya ke tempat sampah.

Penayangan hasil rekapitulasi penilaian diri peserta didik pada siklus 1 belum menumbuhkan perubahan sikap yang berarti. Siswa hanya sekedar mengetahui nilai sikapnya tanpa berkeinginan erubahnya. Refleksi yang diharapkan belum dapat dihayati oleh peserta didik. Hal ini terlihat pada pertemuan ke dua siklus 1, masih ada peserta didik yang belum merubah sikapnya. Walaupun demikian, sudah tampak beberapa peserta didik yang mengalami perubahan sikap seperti sudah mulai mengerjakan PR di rumah, membersihkan tempat praktikumnya, membuang sampah di tempatnya 
serta melaksanakan tugas piket kebersihan kelas. Dari data siklus 1, sudah $60 \%$ peserta didik yang bersikap jujur dan rata-rata $64,5 \%$ peserta didik yang peduli pada lingkungan.

Upaya menumbuhkan karakter IPA pada siklus 1 masih membutuhkan perbaikan pada siklus 2 , sehingga indikator keberhasilan dapat dicapai. Releksi dengan observer pada siklus 1 ditemukan beberapa kelemahan yang harus diperbaiki pada siklus 2. Pada siklus 2 peneliti masih menggunakan cara yang sama dengan siklus 1, tetapi terdapat beberapa perbaikan saat pelaksanaan. Pada siklus 2 ini guru lebih melibatkan peserta didik saat melakukan refleksi. Dari data rekapitulasi penilaian diri pada siklus 2, sudah ada perubahan yang menggembirakan pada sikap peserta didik. Rerata prosentase karakter jujur sebesar $75 \%$ mengalami kenaikan $15 \%$ dari siklus 1 , sedangkan rerata karakter peduli pada lingkungan sebesar 76,5\% mengalami kenaikan $12,2 \%$ dari siklus 1 .

Perbandingan rerata prosentase hasil rekapitulasi penilaian diri peserta didik pada kondisi awal, siklus 1, dan siklus 2 dapat dilihat pada Grafik 1.1.

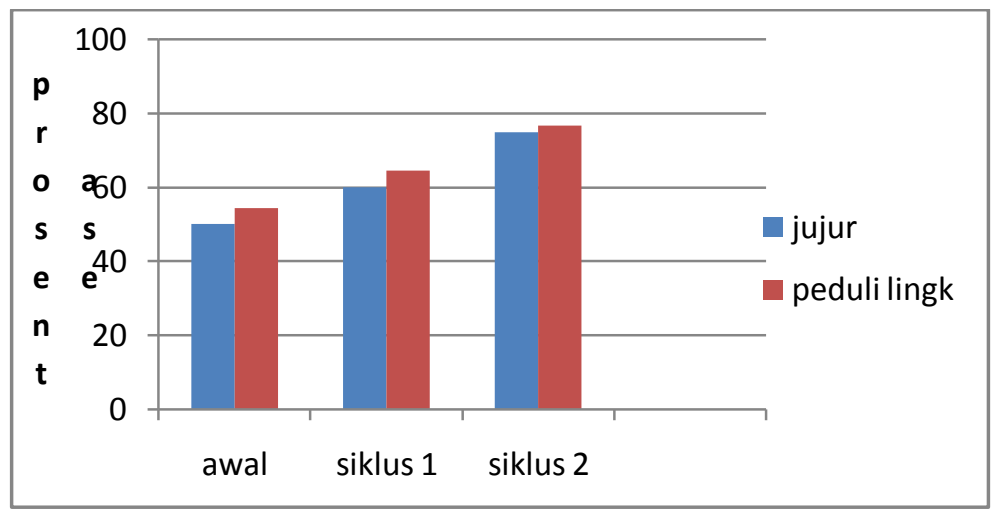

Grafik 1.1. Perbandingan Rerata Prosentase Hasil Rekapitulasi Penilaian Diri

Perubahan karakter jujur dan peduli pada lingkungan pada siklus 2 ini disebabkan karena guru sudah melibatkan peserta didik secara aktif dalam melakukan refleksi terhadap penilaian diri. Pada siklus 2 guru lebih bersemangat dalam memberikan motivasi pada peserta didik akan pentingnya menumbuhkan karakter pada diri peserta didik. Guru membimbing peserta didik dalam melakukan refleksi terhadap apa yang telah dinilainya. Pada saat hasil rekapitulasi penilaian diri ditayangkan, guru memberikan perhatikan khusus pada peserta didik yang masih bersikap kurang baik. Guru menanyakan kepada salah seorang peserta didik, mengapa masih mempunyai nilai 1 pada pernyataan ke-3 yaitu "saya membuang sampah di tempatnya", ternyata diluar dugaan guru, peserta didik tersebut berkata dengan jujur bahwa ketika dia membuang bungkus makanan ke tempat sampah sambil dilemparkan, bungkus makanan tersebut tidak masuk ke dalam tempat sampah, tetapi dia tidak berusaha mengambilnya sehingga dia memberikan jawaban "tidak" pada pernyataan ke-3. Walaupun karakter peduli pada lingkungan belum terbentuk pada diri peserta didik tersebut, tetapi karakter jujur sudah mulai tumbuh dalam diri peserta didik tersebut. Daryanto (2013:109) mengatakan bahwa nilai sikap tidaklah berdiri sendiri, tetapi berbentuk kelompok. Karakter jujur terkait pada nilai jujur, tanggung jawab, peduli, dan nilai lainnya. Seseorang yang sudah mempunyai karakter jujur, maka dalam dirinya akan tumbuh karakter lainnya yang mengikuti seperti tanggung jawab, peduli pada lingkungan, disiplin 
dan karakter lainnya. Guru menyadari bahwa perubahan karakter seseorang tidak dapat dirubah secara cepat, sehingga membutuhkan waktu yang cukup untuk menumbuhkan karakter pada diri peserta didik. Untuk menjadi pribadi yang berkarakter tidak dapat diperoleh secara otomatis, tetapi berkembang melalui proses panjang berkesinambungan dalam pembelajaran.

Perubahan karakter jujur dan peduli pada lingkungan pada siklus 2 ini sudah sesuai dengan indikator keberhasilan yaitu $75 \%$ peserta didik sudah memiliki karakter tersebut. Melalui refleksi penilaian diri peserta didik dapat digunakan sebagai alternatif untuk menumbuhkan karakter IPA yang dalam penelitian ini karakter jujur dan peduli pada lingkungan. Perubahan ini dapat dilihat dengan keadaan kelas sudah mulai bersih karena regu piket sudah melaksanakan tugasnya dengan baik, peserta didik sudah mengerjakan PR di rumah walaupun belum semua peserta didik melakukan hal tersebut, tetapi sudah lebih dari $80 \%$ mereka mengerjakan PR di rumah, ketika diadakan ulangan harian mereka sudah mulai tenang tidak tengok kanan kiri dan kepedulian peserta didik terhadap lingkungannya terutama kelas juga sudah mulai tumbuh, hal ini dapat dilihat saat selesai diadakan praktikum mereka sudah mulai membersihkan tempat praktikum tanpa disuruh guru.

Dengan teknik ini peserta didik diajak secara objektif untuk melihat ke dalam dan keadaan dirinya sendiri, sekali lagi dengan jujur dan jernih. Dampak positif lain dari efektivitas teknik penilaian diri adalah peserta didik akan dikondisikan dan dibiasakan untuk selalu jujur. Dan jika anak selalu menjaga kondisi sikap dirinya, ini sangat positif bagi upaya pembangunan karakter anak. Pembentukan karakter peserta didik tidak hanya tugas guru, tetapi lingkungan keluarga juga sangat mempengaruhi karakter peserta didik, maka seyogyanyalah ada kerja sama yang baik antara pihak sekolah dengan keluarga untuk bersama-sama menumbuhkan karakter peserta didik.

\section{KESIMPULAN}

Berdasarkan hasil penelitian yang dilakukan dapat disimpulkan bahwa melalui refleksi penilaian diri peserta didik dapat menumbuhkan karakter jujur mencapai $75 \%$ dan peduli pada lingkungan mencapai 76,5\% pada siswa kelas VIII D SMP Negeri 1 Bandungan Tahun Pelajaran 2014/2015.

Saran yang dapat diberikan dari hasil penelitian ini adalah untuk dilakukan penelitian lanjutan mengenai karakter IPA yang lainnya yaitu berpikir logis, kritis, kreatif dan inovatif, bergaya hidup sehat, percaya diri, menghargai keberagaman, disiplin, mandiri, bertanggung jawab, dan cinta ilmu. 


\section{DAFTAR PUSTAKA}

Basuni,R.2009. Penilaian Diri Sendiri (Self Assessment) pada Kurikulum Berbasis Kompetensi. Jurnal Saung Guru. Vol.4 No.1 Juli 2009.

Daryanto. 2013. Pendidikan Karakter di Sekolah, Yogyakarta: Gava Media

Fatimah,S. 2011. Pengembangan Asesmen Alternatif dalam pembelajaran Matematika dengan Pendekatan Realistik di Sekolah Dasar. Jurnal Penelitian dan Evaluasi Pendidikan, Tahun 15 No.2, 2011

Haryanto. 2012. Mengapa Perlu Pendidikan Karakter. http://belajarpsikologi.com (diakses 10 November 2014)

M. Khusniati. 2012. Pendidikan Karakter Melalui Pembelajaran IPA. Jurnal Pendidikan IPA Indonesia. Vol.1 N0.2 (2012): 2014-210.

Oci, M. 2012. Model Pendidikan Karakter di Islamic Full Day School (Studi deskritif pada SD Cendekia Leadership School, Bandung). Jurnal Tarbawi Vol 1 No.3 September 2012

Rohman, A. 2011. Penilaian Diri (Self Assessment) dalam Pembelajaran PAI (Makalah Diajukan Untuk Memenuhi Tugas Mata Kuliah "Evaluasi Pendidikan" konsentrasi pendidikan agama islam program pasca sarjana IAIN Sunan Ampel Surabaya 2011/2012)

Saptono. 2011. Dimensi-Dimensi Pendidikan Karakter, Jakarta: Esensi

Sistem Pendidikan Nasional 2003. UU No. 20 tahun 2003.

Reni,A. 2013. Pengembangan Self Assessment sebagai Alat Evaluasi Pendidikan Karakter Berbasis Konservasi pada Mahasiswa Pendidikan Fisika FPMIPA UNNES. Unnes Physic Education Journal 2 (3) 2013.

Tim penyusun. 2010.Bahan Pelatihan Penguatan Metodologi pembelajaran Berdasarkan Nilai-nilai Budaya Untuk Membentuk Daya saing dan Karakter Bangsa: Pengembangan pendidikan Budaya dan Karakter Bangsa. Jakarta: Pukur Badan Penelitian dan Pemgembangan Kementrian Pendidikan Nasional. 